\title{
THE ATTITUDES OF INTERNATIONAL STUDENTS IN INDIA TOWARDS ENGLISH
}

\author{
Wildan Mahir Muttaqin \\ Universitas Muhammadiyah Surakarta \\ hellowildan@gmail.com
}

\begin{abstract}
English is now considered as global language, and with every single day its users are increasing numerously. The paper aims to investigate the international students' attitudes towards English language focusing on a case of International students' in India. As the central university, The English and Foreign Lnguages (EFL) University India has many international students from a wide range of countries. The attitudes are in language skills and in other perspectives. Upon the completion of the collection of data, these were analyzed, computed and tabulated using MS Excel.The study incorporates quantitative approach and has used close ended questionnaire to collect data from the participants. A total number of twenty students participated in the study. From the findings of the data, The research shows that they had shown a positive attitude towards use of English or an increase in the use of English. They believed that learning needs process. Motivation and selfconfidence are also main factors to master English comprehensively. They also believe that EFL University is the best place in India to study English intensively.
\end{abstract}

Keywords: attitudes, international students, English

\section{INTRODUCTION}

English becomes one of the most needed languages in this globalization era to support our life in order not to be left behind from other countries. It has important role since most of the information resources are in English. It has been learned and considered as the first foreign language used in every aspect of modern life such as education, politics, economics, and science. There are about 430 million non-native English speakers, whereas native speakers are 330 million, excluding those who are learning English language (Crystal 2003). Bottery (2000) claims that globalization is mostly associated with English Language supremacy. As English is becoming more and more global language, it's becoming more and more associated with academic achievements for the students in any field. Blumental $(1994,11)$ states that language is the principal means we have to get our ideas and feeling across the other. In spoken language we do not rely on words alone and watch people as they talk, note the gestures, the changing expression, and the tone of the voice. In addition, most of the world's language learners study English in order to be able to communicate fluently.

English is one of the knowledge that is important to learn for people all over the world. One of the most important parts is that English functions as the instrument of communication. This suggests that learning English is not only learning the vocabulary and structure but also learning how to apply and use this language for communication. As an international language, English is very important and has many interrelationships with various aspects of the life human beings. Learning English covers four skills: reading, listening, speaking and writing. All of the skills are learned in order to achieve integrated skill. When someone was born, he learns how to speak, and speaking can make him to communicate 
or contact with other person (Yorkey 1990). Speaking is important to learn especially for students of Junior High School to enrich their vocabulary. Besides that, by mastering speaking they get experience and knowledge from many kinds of media communication that related to English. For instance, they can get knowledge from the movie, internet, newspaper, and magazines. The factors that influences someone's ability in speaking are knowledge of language systems include grammar, vocabulary, pronunciation, and the knowledge of topic discussion. Bi/multilingualism allows people to grow up with access to two or more languages and this allows people to show different attitudes towards languages.

\section{LANGUAGe AtTitude}

Attitude is a central part of human identity. Everyday people love, hate, like, dislike, favour, oppose, agree, disagree, argue, persuade etc. All these are evaluative responses to an object. Hence attitudes can be defined as a summary evaluation of an object of thought (Bohner \& Wänke 2002). They are inclinations and predispositions that guide an individual's behaviour (Rubinstein 1986) and persuade to an action that can be evaluated as either positive or negative (Fishbein \& Ajzen 1975). Attitudes develop and change with time (Rubinstein 1986). There are various definitions of the word attitude given by previous researchers. Attitude studies are important to acquire personal feedbacks on a phenomenon. According to Anderson (1994), there are five components in attitude which are emotion, goal, direction, strength and consistency. Each attitude component is divided into positive, neutral and negative. From psychological point of view, attitude is viewed as a mental condition that exists in a person, shaped through experience and will influence a person's reaction towards an object or related phenomenon. Attitude is processed through learning and implicit in nature (Tay Meng Guan 2003)

Regarding with attitude study, Gardner Proposed that attitude is the overall feelings of a person towards any particular thing (Gardner 1980). Attitude of a person is positive or of negative attributes to anything (Ajzan, 1988). Baker defined attitudes as a person persistent way of behaving in particular way (Baker 1992). Gardner proposed that attitude is an important element in language learning (Gardner 1985). Meanwhile, Wenden (1991) gives a new dimension to attitude concept by dividing into three elements, namely: cognitive, evaluative and behavioral which all works together. The concept has the same model of Attitude proposed by Eagly \& Chaiken (1993), attitudes are influenced by three components. They are cognitive (beliefs, thoughts, attributes), affective (feelings, emotions) and behavioural information (past events, experiences) (G. Maio, GR. Maio, \& Haddock 2010). Bernat and Gvozdenko while discussing social factors upon language learning, place attitude with them for having its effect on language learning (Bernat \& GvozdenkoI. 2005). Csizer and Donyei draw same conclusion in their research and place attitude at an important position for language learning (Csizer \& Dornyei Z, 2005).

Attitude defines or promotes certain behaviors and explains their direction and persistence. It is a convenient and efficient way of explaining consistent patterns in behaviour. It often manages to summarize, explain and predict behaviour (Baker 1992). Attitudes, according to Crystal (1997, 215), are the feelings people have about their own language or the languages of others. Allport (1935) defines,"attitude is a mental or neural state of readiness, organized through experience, exerting a directive or dynamic influence upon the individual's response to all objects and 
situations with which it is related" (cited in Baker 1992, 11). Thus, attitude to language is a construct that explains linguistic behaviour in particular. The evaluation that a particular language is harsh, sweet, difficult, easy, international, local, prestigious or vernacular is due to the variation of attitudes towards the language. Therefore, attitude change is an important notion since attitudes are affected by experience. There may be both positive and negative feelings attached to a language. The major dimensions along which views about languages can vary are 'social statuses' and 'group solidarity' (Hohenthal 2003). Baker (1992, 11) quotes Ajzen (1988) who says, attitude is 'a disposition to respond favourably or unfavourably to an object, person, institution, or event'. It means that if a speech community shows their unfavourablity to a particular language, that language is unlikely to survive and vice-versa. Another researcher proposes attitude is one of the key elements for learning language (Karahan 2007), (Starks \& Paltridge 1996). It is a variable thing and it can be changed governing to many external as well internal personality factors of a person. After the British left India, even than people of the sub-continent and particularly in Pakistan do not want to study English as they considered English language learning as a mark of slavery. But this attitude about English language learning is now changed as English has acquired a status of global language (Bamgbose 2001).

Language attitudes vary in nature. People show attitudes of varying nature such as attitude to the variation of language; attitude to minority language and dominant language; attitude to foreign and second language; attitude to a specific language etc. Whatever the nature of attitude, it has two components: instrumental and integrative (Baker 1992). Instrumental attitude refers to showing attitude to a particular language for self-achievement and recognition. As Hohenthal (2003) reports that attitude to English in India is instrumental: English is perceived as a useful language to know mostly because of job opportunities and for education. People favour a particular language when they find that the language is a tool to achieve high status, economic advantage, basic security and survival and matters related to self-orientation. Integrative attitude, on the other hand, concerns someone's attachment with a particular speech community. People show such attitude in order to be identified as a member of the desired community. Instrumental and integrative orientation to language attitudes are not necessarily opposite and alternatives, rather complementary to each other. A person may be motivated in different strengths by both orientations (Baker 1992).

The problem can be formulated as what is the attitude of the International students of English and Foreign languages (EFL) University, India towards English? Also this study finds it relevant to investigate attitudes of the International students of English and Foreign languages (EFL) University towards English that consists of Listening and Speaking; and Reading and Writing. The objectives of the study is to know the attitude of the International students of English and Foreign languages (EFL) University towards English language and to describe attitudes of the International students of English and Foreign languages (EFL) University towards English that consists of Listening and Speaking; and Reading and Writing. Attitude has been studied from various perspectives with reference to a number of languages in a variety of settings such as attitude towards mother tongue; attitude towards a 
second or foreign language; attitude towards national language; attitude towards varieties of languages; attitude towards language in education policy; relationship between attitudes and motivation; the relationship between attitudes and learning strategies; the relationship between attitudes and level of achievement.

\section{EFL UnIVERsity Profile}

The English and Foreign Languages University is located in Hyderabad, an Indian city that is more than four hundred years old. Founded in 1958 as the Central Institute of English (CIE), it was renamed the Central Institute of English and Foreign Languages (CIEFL) in 1972 with the addition of three major foreign languages. In 2006 it was given central university status and accordingly came to be called the English and Foreign Languages University. Dedicated to the study of English and foreign languages, it is the only one of its kind in South Asia. It has been specially set up to conduct advanced research and training in English and foreign languages (Arabic, Chinese, French, German, Spanish, Italian, Russian, Japanese, Korean, Persian, Turkish) in the areas of Teacher Education, Literature, Linguistics, Interdisciplinary and Cultural Studies.

The English and Foreign Languages University was founded with the singular vision of developing competency building teacher education and training in the country.The mandate of the University is to advance and disseminate "in-structional, research and extension facilities in the teaching of English and Foreign Languages and Literatures in India" as well as "to take appropriate measures for interdisciplinary studies and research in literary and cultural studies, and to develop critical intercultural understanding of civilizations". With its unique mandate to build teacher competency in language and literary pedagogy, the university has steadily enhanced its expertise in areas of language education, pedagogical and evaluative methods, material production, the sciences of linguistics and phonetics, in English and Foreign Languages. Three generations of teachers from primary to tertiary levels from across the country and abroad were trained at CIEFL/EFLU. The University has two regional centres, one each at Lucknowand Shillong, to cater for the needs of the students of the Northern and North-eastern regions respectively. The regional centres run their own programmes andcourses of study. They have their own libraries and hostel facilities.

\section{Participants' Profile}

The researcher observed twenty international students at EFL University. They were mostly at the first year or fresher. International students are the students from various countries outside India. At the EFL University they can meet their highest expectations and the university provides them with all the support services necessary to ensure that they have a rewarding experience, both academically and socially. They come from a wide range of countries such as Indonesia, Oman, Turkmenistan, Syiria, China, Bhutan, Afghanistan, Russia, Tajikistan, Uzbekistan, Yemen, Eritrea, Bhutan, Turkey, Iraq, Nepal, Bangladesh and other countries. The respondents are eleven male students and nine female students.

\section{METHODOLOGY}

This is a quantitative study which explores International Students' Attitudes towards English at EFL University. Quantitative approach is one in which the investigator primarily uses post positivist claims for developing knowledge (i.e, cause and effect thinking, reduction to specific variables and hypotheses and 
questions, use of instrument and observation, the test theories), employs strategies of inquiry such as experiments and surveys and collects data on predetermined instruments that yield satistical data (Creswell 2003). Survey entails the collection of data by using questionnaire to discover the opinions of a population, based on a sample of the population (Creswell 2009). Moreover there are many techniques used to collect data which include interviews, telephone calls, and observation (tharenou, Donohue \& Cooper 2007).

A popular method of collecting data for surveys is using likert scales, these are used for measuring attitudes which require respondents to choose a statement from a number of statements that range from 'strongly agree' to 'strongly disagree' (Zikmund 2003; Saunders, Lewis \& Thornhill 2007). The respondent usually choses a response from a set of five statements where each response is assigned a weight which allows the researcher to perform statistical analysis (Zikmund 2003). The choice that the respondent makes means means that they agree with the statements they have chosen which allows them to express their feelings (Zikmund 2003).

The researcher used a likert scale that adopted a 5 point scale for his study, instead of a 7 point likert scale because 5 point scales reduce the level of frustation among respondents, and increases the rate and quality of the responses (Buttle 1996; Prayag 2007). A likert scale was used in this study which asked international students to best describe the way they feel about English as: 1 strongly agree, 2 agree, 3 neutral; 4 strongly disagree, 5 disagree. Likert scales require the respondent to state the extent to which they agree or disagree with a series of statements about the attitude object. Each response is given a score and the item scores are then summed to produce an overall score that indicates the respondent's attitude.

The data were collected by the researcher himself from all the participants, monitoring and guiding the participants for correct filling of the questionnaire. Participants were selected from different countries and different study program, so as to represent the data equally. The study does not utilize gender base discrimination as well and both male/female genders have equal value in the study. After collecting the data, $\mathrm{ms}$ excel is being utilized to interpret the data, after interpretation of data, its frequencies were also measured. Table presentation of the results of the findings is incorporated.

\section{FINDINGS AND DISCUSSIONS}

The following sections discuss the findings. It includes a description of the demographic profile of the respondents followed by a discussion on the International Students' Attitudes towards English at EFL University. The result is divided into three parts. They are Student's attitudes towards Listening and Speaking, Student's attitudes towards Reading and Writing, and Student's attitudes from various perspectives. Respondents' attitudes towards English language were obtained through the use of a five-point Likert scale questionnaire with $5=$ strongly agree (SA), $4=$ agree (A), 3 $=$ neutral $(\mathrm{N}), 2$ disagree (DA), and $1=$ strongly disagree (SDA). The researcher gave 20 statements which consist of attitudes towards L \& S, R \& , and other perspectives.

\section{Students' Attitudes towards Listening and Speaking}

Listening and speaking are very important in communication. Based on the nature of language, we can see that children acquire language from the stage of listening then speaking. In this result, Student's attitudes towards Listening and Speaking will be the first 
discussion. The respondents were asked to provide their opinion on six statements regarding their attitudes towards Listening and Speaking. Among the statements, the first four impression for him/her. Thus, it can apparently be said that the respondents have positive attitude towards Listening and Speaking (Table 1)

Table 1: Students'Attitude towards Listening and Speaking

\begin{tabular}{|c|c|c|c|c|c|c|c|}
\hline No & Questions & SA & A & $\mathbf{N}$ & DA & SDA & Total \\
\hline 1 & Speaking English is an advantage & $60 \%$ & $40 \%$ & $0 \%$ & $0 \%$ & $0 \%$ & $100 \%$ \\
\hline 2 & $\begin{array}{l}\text { I dislike people who speak to me in } \\
\text { English }\end{array}$ & $0 \%$ & $0 \%$ & $5 \%$ & $45 \%$ & $50 \%$ & $100 \%$ \\
\hline 3 & $\begin{array}{l}\text { When someone speaks English I } \\
\text { think he/she is educated }\end{array}$ & $5 \%$ & $35 \%$ & $35 \%$ & $25 \%$ & $0 \%$ & $100 \%$ \\
\hline 4 & $\begin{array}{l}\text { Making friends with international } \\
\text { students at EFLU will increase } \\
\text { students' speaking skill in English }\end{array}$ & $50 \%$ & $45 \%$ & $0 \%$ & $5 \%$ & $0 \%$ & $100 \%$ \\
\hline 5 & $\begin{array}{l}\text { There should be more TV and radio } \\
\text { programs in English }\end{array}$ & $15 \%$ & $75 \%$ & $5 \%$ & $5 \%$ & $0 \%$ & $100 \%$ \\
\hline 6 & $\begin{array}{l}\text { When someone speaks English it } \\
\text { creates a good impression for } \\
\text { him/her }\end{array}$ & $10 \%$ & $50 \%$ & $40 \%$ & $0 \%$ & $0 \%$ & $100 \%$ \\
\hline
\end{tabular}

statements elicited respondents' perception and impression about English L \& S which is shown in table 1 below. $60 \%$ respondents strongly agreed and $40 \%$ of them agreed that Speaking English is an advantage. $50 \%$ respondents strongly disagreed and $45 \%$ of them disagreed and $5 \%$ is neutral in giving statement that I dislike people who speak to me in English. In the question When someone speaks English I think he/she is educated (both agreed and neutral were same $35 \%, 25 \%$ disagreed, and $5 \%$ strongly agreed). Dealing with campus life, $50 \%$ respondents strongly agreed and $45 \%$ of them agreed and $5 \%$ is disagreed in giving statement that making friends with international students at EFLU will increase students' speaking skill in English. A majority of the respondents (15\% strongly agreed and $75 \%$ agreed) and only 5\% neutral, and 5\% disagreed opined that there should be more TV and radio programs in English. Then, $50 \%$ agreed, $10 \%$ strongly agreed, and $40 \%$ neutral) stated that When someone speaks English it creates a good

\section{Student's Attitudes towards Reading and Writing}

Other aspects in mastering language are Reading and Writing. The respondents were asked to provide their opinion on six statements regarding their attitudes towards Reading and writing. Among the statements, the first four statements elicited respondents' perception and impression about English R \& W which is shown in table 2 below. In media domain, the respondents opined (35\% neutral, $30 \%$ agreed, $15 \%$ strongly agreed, and $20 \%$ disagreed) that all official documents should be in English. In developing students' competence, the respondents opined (55\% agreed, 35\% strongly agreed, and 10\% neutral) that Making an English Diary can Improve Students' writing skill in English. Then the researcher gave the statements If an academic text is available in English, I will enjoy reading the text, the result was $60 \%$ agreed, $10 \%$ strongly agreed, 25\% neutral, and 5\% disagreed. Then, given the statement Only English must be used in advertisements, public signs, map etc, 
the result was $15 \%$ agreed, $35 \%$ neutral, and 40\% disagreed, and 10\% strongly disagreed. As the emphasizing, $15 \%$ of the respondents strongly agreed, $55 \%$ of them agreed, $25 \%$ neutral, $5 \%$ disagreed with the statement that English should be used in advertisements, public signs, map etc. They also gave their responses with almost similar percentage of frequency $(25 \%$ of the respondents strongly agreed, 55\% of them agreed, 15\% neutral, 5\% disagreed) that they liked to read more newspapers and magazines in English (e.g. The Times of India, Deccan Chronicle, The Hindu, The Hans India, etc). This pattern of choice indicates that though the respondents had perspectives. In this section, the statements were about the students' motivation and dealing with their future. The respondents were asked to provide their opinion on eight statements regarding their attitudes from various perspectives. Among the statements, the first four statements elicited respondents' perception and impression about English and their responses about liking and disliking of English language which is shown in table 3 below. $70 \%$ respondents strongly agreed and $30 \%$ of them agreed that they like speaking English. Then, respondents' opinion on global status and importance of English language which is shown in table 3 . Most of the respondents (40\%

Table 2: Students'Attitude towards Reading and Writing

\begin{tabular}{|c|c|c|c|c|c|c|c|}
\hline No & Questions & SA & A & $\mathbf{N}$ & DA & SDA & Total \\
\hline 7 & $\begin{array}{l}\text { All official documents should be } \\
\text { in English }\end{array}$ & $15 \%$ & $30 \%$ & $35 \%$ & $20 \%$ & $0 \%$ & $100 \%$ \\
\hline 8 & $\begin{array}{l}\text { Making an English Diary can } \\
\text { Improve Students' writing skill in } \\
\text { English }\end{array}$ & $35 \%$ & $55 \%$ & $10 \%$ & $0 \%$ & $0 \%$ & $100 \%$ \\
\hline 9 & $\begin{array}{l}\text { If an academic text is available } \\
\text { in English, I will enjoy reading } \\
\text { the text }\end{array}$ & $10 \%$ & $60 \%$ & $25 \%$ & $5 \%$ & $0 \%$ & $100 \%$ \\
\hline 10 & $\begin{array}{l}\text { Only English must be used in } \\
\text { advertisements, public signs, map } \\
\text { etc. }\end{array}$ & $0 \%$ & $15 \%$ & $35 \%$ & $40 \%$ & $10 \%$ & $100 \%$ \\
\hline 11 & $\begin{array}{l}\text { English should be used in } \\
\text { advertisements, public signs, road } \\
\text { signs, map etc }\end{array}$ & $15 \%$ & $55 \%$ & $25 \%$ & $5 \%$ & $0 \%$ & $100 \%$ \\
\hline 12 & $\begin{array}{l}\text { I would like to read more Indian } \\
\text { newspapers and magazines in } \\
\text { English (e.g. The Times of India, } \\
\text { Deccan Chronicle, The Hindu, The } \\
\text { Hans India, etc) }\end{array}$ & $25 \%$ & $55 \%$ & $15 \%$ & $5 \%$ & $0 \%$ & $100 \%$ \\
\hline
\end{tabular}

shown a positive attitude towards use of English or an increase in the use of English in media and also developing the students' ability both reading and writing (Table 2 ).

\section{Student's Attitudes from Various Perspectives}

Another result to discuss is Student's attitudes from various strongly agreed, 55\% agreed, and 5\% disagreed) opined that English is an important lingua franca in globalization. They also reported with commendable percentage (20\% strongly agreed, $70 \%$ agreed, and $10 \%$ neutral) that it is needed to increase the use of English in this era of globalization. It is apparent from the data of the table 
that the respondents recognize the global status and importance of English language in this era of globalization and global communication network. This is indeed an expression of positive attitudes of the respondents towards English language. The respondents also believe in process that Language is Habit $\quad(35 \%$ strongly agreed, 60\% inclined to the increase use of English language in education domain. Besides, they stated that Motivation and selfconfidence are main factors to master English comprehensively (35\% strongly agreed and $65 \%$ agreed), so both of them are very important for International students. Then the last is about studying more English both at EFL University and in India, 30\%

Table 3: Student's Attitudes from Various Perspectives

\begin{tabular}{|c|c|c|c|c|c|c|c|}
\hline No & Questions & SA & A & $\mathbf{N}$ & DA & SDA & Total \\
\hline 13 & I like speaking English & $70 \%$ & $30 \%$ & $0 \%$ & $0 \%$ & $0 \%$ & $100 \%$ \\
\hline 14 & $\begin{array}{l}\text { English is an important lingua } \\
\text { franca in globalization }\end{array}$ & $40 \%$ & $55 \%$ & $0 \%$ & $5 \%$ & $0 \%$ & $100 \%$ \\
\hline 15 & $\begin{array}{l}\text { Language is habit, so Learning } \\
\text { English needs process }\end{array}$ & $35 \%$ & $60 \%$ & $5 \%$ & $0 \%$ & $0 \%$ & $100 \%$ \\
\hline 16 & $\begin{array}{l}\text { We need to increase the use of } \\
\text { English in this era of globalization }\end{array}$ & $20 \%$ & $70 \%$ & $10 \%$ & $0 \%$ & $0 \%$ & $100 \%$ \\
\hline 17 & $\begin{array}{l}\text { Knowledge of English offers } \\
\text { advantages in seeking good jobs } \\
\text { and reaching better positions at } \\
\text { company }\end{array}$ & $45 \%$ & $50 \%$ & $0 \%$ & $5 \%$ & $0 \%$ & $100 \%$ \\
\hline 18 & $\begin{array}{l}\text { I need English in order to } \\
\text { succeed in higher education }\end{array}$ & $30 \%$ & $65 \%$ & $0 \%$ & $5 \%$ & $0 \%$ & $100 \%$ \\
\hline 19 & $\begin{array}{l}\text { Motivation and self-confidence are } \\
\text { main factors to master English } \\
\text { comprehensively }\end{array}$ & $35 \%$ & $65 \%$ & $0 \%$ & $0 \%$ & $0 \%$ & $100 \%$ \\
\hline 20 & $\begin{array}{l}\text { I would like to study more English } \\
\text { both at EFLU and in India }\end{array}$ & $30 \%$ & $60 \%$ & $5 \%$ & $5 \%$ & $0 \%$ & $100 \%$ \\
\hline
\end{tabular}

agreed, and 5\% neutral). They also opined (45\% strongly agreed, 50\% agreed, and $5 \%$ disagreed) that knowledge of English offers advantages in seeking good jobs. It can be seen from the responses of the respondents, they realized that knowledge of English offers advantages in this era of globalization when getting a good job, securing a better social position and personal establishment is very competitive. the majority of the respondents $(30 \%$ strongly agreed, $65 \%$ agreed, 5\%disagreed) reported that they need English in order to succeed in higher education. What is apparent from Table 3 is that the respondents have a positive attitude towards English language as they are respondents strongly agreed, $60 \%$ of them agreed, 5\% neutral, and 5\% disagreed. So, it also indicates that EFL University is the best place in India to study English intensively (Table 3).

\section{CONCLUSION}

They are three parts of International Students' Attitudes towards English at EFL University. The first is Student's attitudes towards Listening and Speaking. The second is Student's attitudes towards Reading and Writing. The last is Student's attitudes from various perspectives. Then, the respondents had shown a positive attitude towards use of English or an increase in the use of English in media and also developing the students' ability both reading and 
writing. From the data of the table that the respondents recognize the global status and importance of English language in this era of globalization and global communication network. Then, the respondents have a positive attitude towards English language as they are inclined to the increase use of English language in education domain. They stated that Motivation and selfconfidence are main factors to master English comprehensively. They also believe that EFL University is the best place in India to study English intensively.

\section{REFERENCES}

Allport, GW. 1954. The Historical Background of Modern Social Psychology. InG

Bamgbose, Ayo. 2001. "World Englishes and Globalisation". World Englishes 20 (3): 357-363

Blumental, Josep C. 1994. The English Language. New York: HarcourT, Brace, and World. Inc.

Bohner, G \& M Wänke. (2002). Attitudes and Attitude Change. Psychology Press

Bottery, M. 2000. Education, Policy and Ethics. London: Continuum

Brown, H. Douglas. 1994. Teaching By Principles: An Interactive Approach to Language Pedagogy. New York: Longman

Creswell, J. 2009. Research Design: Qualitative, Quantitative, and Mixed Methods Approaches. Los Angeles: Sage

Crystal, David. 2003. English as a Global Language, 2nd edition. Cambridge: Cambridge University Press
D. Crystal, 1997. A Dictionary of Linguistics and Phonetics (4th ed.). UK: Blackwell

Fishbein, M, \& Ajzen, I. 1975. Belief, Attitude, Intention and Behavior: An Introduction to Theory and Research. Reading: Addison-Wesley

Hague, Paul 2002. Market Research: A Guide to Planning, Methodology \& Evaluation. 3 Edition. Lontoo: Kogan Page

Karahan, F. 2007. "Language Attitudes of Turkish Students towards the English Language and Its Use in Turkish Context”. Journal of Arts and Sciences. May: 73-87

Lindzey (ed.), Handbook of Social Psychology Vol. 1. Cambridge: AddisonWesley

Mamun, Sk. Abdullah. 2012. 'Students' Attitudes towards English: The Case of Life". Science School of Khulna University. 3 (1): 200-209

Nunan, David. 1992. Research Methods in Language Learning. Cambridge: Cambridge University Press.

Richards, Jack C. 2001. Approaches and Methods in Language Teaching. Cambridge: Cambridge University Press

Rubinstein, M. F. 1986. Tools for Thinking and Problem Solving. New Jersey: Prentice Hall

Tharenou, P, Donohue, R, and Cooper, B 2007. Management Research Methods. New York: Cambridge University Press

Wenden, A. 1991. Learner Strategies for Learner Autonomy. London: Prentice-Hall lnternational.

www.efluniversity.ac.in accesed on March 1,2016

Yorkey, Richard. 1990. Study Skill for Students of English as a Second Language. New York: McGraw-Hill,. Inc. 